\title{
DISCLOSING AGENT FROM RED DRAGON FRUIT PEEL AS DENTAL PLAQUE INDICATOR
}

\author{
Eky Purbaningtyas*, Fifin Yuliani*, Arief Putra Ananda**, Rezmelia Sari***
}

*Program Studi Kedokteran Gigi, Fakultas Kedokteran Gigi, Universitas Gadjah Mada, Yogyakarta, Indonesia

**Program Studi Farmasi, Fakultas Farmasi, Universitas Gadjah Mada, Yogyakarta, Indonesia

***Departemen Periodonsia, Fakultas Kedokteran Gigi, Universitas Gadjah Mada, Yogyakarta, Indonesia

Correspondence : Program Studi Kedokteran Gigi, Fakultas Kedokteran Gigi, Universitas Gadjah Mada, Yogyakarta, Indonesia

Email : eky.purbaningtyas@mail.ugm.ac.id

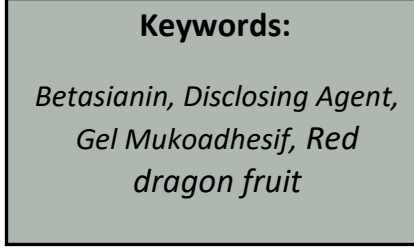

\section{PENDAHULUAN}

Radang gusi atau gingivitis adalah penyakit inflamasi pada gusi yang memiliki ciri gusi kemerahan, sedikit bengkak, dan terjadi perdarahan saat menyikat gigi. Kondisi radang gusi dapat menjadi tanda awal perkembangan penyakit periodontitis kronis ${ }^{1,2}$. Berdasarkan RISKESDAS 2018 prevalensi penyakit periodontitis di Indonesia cukup tinggi yaitu sebesar $75,1 \%{ }^{3}$.

Salah satu faktor risiko penyakit periodontal yaitu akumulasi plak pada permukaan gigi, di atas tepi gusi, maupun di bawah tepi gusi. Akumulasi plak akan mengaktifkan respon imun host terhadap perubahan inflamasi pada jaringan periodonsium. Inflamasi dapat memicu terjadinya kerusakan dan lepasnya perlekatan jaringan periodontal $\left.\right|^{4,5}$.
Plak gigi adalah lapisan tipis putih kekuningan dan transparan yang terbentuk karena adanya kolonisasi bakteri, serta tidak mengalami mineralisasi ${ }^{6,7}$. Pencegahan penyakit periodontal dapat dilakukan dengan menghilangkan plak gigi oleh setiap individu dengan cara sikat gigi. Pembersihan plak akan lebih optimal dengan visualisasi plak gigi dengan bahan pewarna yang disebut disclosing agent ${ }^{6,8}$.

Disclosing agent bekerja dengan memberikan warna pada bakteri dalam plak sehingga terdapat perbedaan warna antara gigi dan plak gigi. Beberapa macam disclosing agent telah ditemukan dengan berbagai jenis zat warna antara lain iodine, gentian violet, eritrosin, basic fuschin, dan three-tone disclosing agent. Three-tone 
disclosing agent dapat menampilkan tiga warna berbeda berdasar pH plak. Disclosing agent ini memiliki kandungan rose bengal, brilliant blue, dan $\mathrm{FCF}^{6,5}$. Keuntungan dari penggunaan disclosing agent yaitu pasien dapat melakukan penilaian mandiri terhadap plak gigi, meningkatkan kesadaran akan pentingnya pembersihan plak gigi, dan pasien dapat mengetahui area yang terdapat plak sehingga pembersihan menjadi optimal6.

Disclosing agent dapat dibuat dengan bahan alami salah satunya kandungan zat warna betasianin. Betasianin merupakan zat warna dari pigmen yang bersifat polar yang dikategorikan dalam pigmen betalain ${ }^{9}$. Betasianin memiliki fungsi sebagai anti-inflamasi, antioksidan, antibakteri, antivirus, dan antiprotozoal ${ }^{10}$. Bahan alami yang memiliki kandungan betasianin salah satunya yaitu pada kulit buah naga merah (Hylocereus polyrhizus) $)^{9}$.

Kulit buah naga merah menempati $30-35 \%$ bagian dari keseluruhan buah naga merah. Pemanfaatan kulit buah naga merah masih cukup rendah, sehingga menjadi limbah rumah tangga. Sedangkan pada kulit buah naga merah terdapat kandungan zat warna betasianin yang dapat menjadi alternatif sebagai bahan alami pembuatan disclosing agent ${ }^{11}$. Disclosing agent berbahan kulit buah naga merah dapat dibuat dengan sediaan gel. Gel merupakan sediaan yang bersifat stabil, memiliki penampilan yang menarik, serta penghantar yang baik untuk aplikasi obat pada jaringan kulit atau membran mukosa ${ }^{12}$.

Berdasarkan pendahuluan di atas penelitian ini memiliki tujuan untuk mengetahui potensi betasianin kulit buah naga merah (Hylocereus polyrhizus) dalam formula gel sebagai alternatif disclosing agent yang murah, alami, dan aman untuk mewarnai plak gigi.

\section{METODE PENELITIAN}

Jenis penelitian ini merupakan Experimental Research yang dilakukan di Fakultas Kedokteran Gigi UGM dan Fakultas farmasi UGM. Penelitian ini telah mendapatkan surat ijin kelaikan penelitian yang diterbitkan oleh Komisi Etik Fakultas Kedokteran Gigi UGM. No.0096/KKEP/FKG-UGM/EC/2019.

\section{Identifikasi Tanaman}

Tabel 1. Identifikasi Tanaman Buah Naga Merah

\begin{tabular}{lll}
\hline No. & Karakteristik & Keterangan \\
\hline 1. & Nama & Buah Naga Meraah \\
\hline 2. & Nama Latin & Hylocereus polyrhizus \\
\hline 3. & Warna & Merah keunguan \\
\hline 4. & Berat & $300-500$ gram \\
\hline
\end{tabular}

\section{Ekstraksi Kulit Buah Naga Merah}

Metode ekstraksi kulit buah naga merah yaitu dengan metode maserasi menggunakan pelarut etanol $96 \%$. Kulit buah naga merah dipotongpotong menjadi bagian yang kecil. Kemudian ditimbang sebanyak $\pm 8000 \mathrm{~g}$ dan dimaserasi dalam pelarut etanol $96 \%$ selama 24 jam pada suhu kamar $\left(25^{\circ} \mathrm{C}\right)$, kemudian ditambahkan asam askorbat $1 \%$ sampai $\mathrm{pH}$ larutan menjadi 4,5 . Pemisahan residu dilakukan dengan penyaringan. Selanjutnya penguapan pelarut dilakukan dengan waterbath sampai didapatkan ekstrak yang kental. Ekstraksi dilakukan di Laboratorium Galenika Departemen Biologi Farmasi Fakultas Farmasi UGM.

\section{Uji Kandungan Betasianin}

Uji ini dilakukan dengan alat Spektrofotometer UV-Vis dengan pengamatan pada panjang gelombang maksimum betasianin yaitu $537 \mathrm{~nm}$. Ekstrak diencerkan 0,5 ml ekstrak kental kulit buah naga merah dengan $4,5 \mathrm{ml}$ etanol dalam labu takar. Kemudian, diambil 0,5 ml sampel yang telah diencerkan ke dalam labu takar. Lalu, 
ditambahkan larutan buffer $\mathrm{pH} \quad 4,5$ dengan perbandingan 1:5 (sampel:buffer).

Keterangan :

$\operatorname{Kadar}$ Betasianin $(\mathrm{mg} / \mathrm{l})=\frac{A \times F P \times B M \times 1000}{\Sigma \times L}$

A $=$ Absorbansi

$\mathrm{FP}=$ Faktor pengenceran $(1 \mathrm{x})$

$\mathrm{BM}=$ Berat molekul betasianin $(550 \mathrm{~g} / \mathrm{mol})$

$\Sigma=$ Koefisien absorbansi $(60.000 \mathrm{l} / \mathrm{mol})$

$\mathrm{L}=$ Tebal kuvet $(1 \mathrm{~cm})$

\section{Pembuatan Gel Mukoadhesif}

Komposisi formula gel mukoadhesif ekstrak kulit buah naga merah ditunjukkan melalui tabel 2 .

Tabel 2. Komposisi Formula Gel Mukoadhesif Ekstrak Kulit Buah Naga Merah

\begin{tabular}{lcc}
\hline $\begin{array}{c}\text { Komponen } \\
\text { Formula }\end{array}$ & Formula 1 & Formula 2 \\
\hline Ekstrak & $10 \%$ & $15 \%$ \\
\hline Karbopol 940 & $2 \%$ & $2 \%$ \\
\hline Gliserin & $30 \%$ & $30 \%$ \\
\hline TEA & $2 \%$ & $2 \%$ \\
\hline Asam askorbat & $0,1 \%$ & $0,1 \%$ \\
\hline Akuades ad & $100 \mathrm{ml}$ & $100 \mathrm{ml}$ \\
\hline
\end{tabular}

Pembuatan sediaan gel diawali dengan terlebih dahulu Karbopol 940 didispersikan ke dalam $50 \mathrm{~mL}$ akuades, kemudian ditambahkan TEA secukupnya hingga terbentuk basis gel. Kemudian gliserin ditambahkan dalam campuran tersebut. Akuades yang tersisa ditambahkan ke dalam campuran formula hingga bobot mencapai 100 gram. Setelah semua bahan tercampur, ekstrak kulit buah naga merah ditambahkan kemudian diaduk hingga homogen. Sediaan gel mukoadhesif diformulasikan ke dalam dua formula gel dengan variasi ekstrak kulit buah naga merah konsentrasi $10 \%$ dan $15 \%$.

\section{Uji Kontrol Kualitas Gel Mukoadhesif}

\section{a. Uji Organoleptis}

Uji organoleptis dilakukan dengan mengamati bau, warna, dan bentuk dari sediaan. Uji ini dilakuan secara makroskopis terhadap sediaan. Memiliki beberapa persyaratan yaitu memiliki warna seperti zat aktif, memiliki aroma khas ekstrak kulit buah naga merah, dan penampilan kental.

\section{b. Uji Daya Lekat}

Uji daya lekat dilakukan dengan cara meletakkan sediaan di atas obyek gelas dengan luas area 2x $2 \mathrm{~cm}$ yang kemudian diletakkan obyek gelas yang lain diatas sediaan tersebut dan ditekan dengan beban $1 \mathrm{~kg}$ selama 5 menit. Setelahnya, dipasang obyek gelas pada alat uji, lalu dilepaskan beban sebesar $80 \mathrm{~g}$ dan dicatat waktunya hingga kedua obyek gelas terlepas.

\section{c. Uji Daya Sebar}

Uji daya sebar dilakukan dengan cara sediaan gel ditimbang sebanyak 0,5 gram. Setelah itu, letakkan gel tepat di bawah kaca bulat yang di bawahnya disertai dengan skala diameter, kemudian ditutup kaca lain yang telah ditimbang dan dibiarkan selama satu menit, setelah itu diukur diameter sebarnya. Setelah 1 menit, diberikan tambahan beban sebesar 50 gram dan tunggu selama 1 menit. Kemudian diukur diameter sebarnya. Hal yang sama dilakukan tiap 1 menit dengan penambahan beban 50 gram hingga total beban yang ditambahkan sebesar 250 gram untuk melihat pengaruh beban terhadap diameter sebar sediaan gel.

\section{Uji Klinis}

Kriteria subjek pada penelitian ini yaitu lakilaki atau perempuan berusia 17-22 tahun, sehat, 
dan tidak sedang dalam masa pengobatan. Sebelum ditetapkan sebagai responden penelitian seluruh subjek diminta untuk mengisi informed consent. Pemeriksaan klinis plak dilakukan terhadap 16 orang responden yang telah menyetujui informed consent dan dibagi dalam dua kelompok yaitu kelompok dengan pengaplikasian gel mukoadhesif ekstrak kulit buah naga merah konsentrasi $10 \%$ dan kelompok dengan pengaplikasian gel mukoadhesif ekstrak kulit buah naga merah konsentrasi $10 \%$. Responden diberi edukasi untuk tidak menggosok gigi pada pagi hari, tidak berpuasa, dan pemeriksaan dilakukan dalam dua hari berturut pada siang hari. Seluruh responden diberi perlakuan pengaplikasian bahan gel mukoadhesif kulit buah naga merah, lalu dilakukan penilaian skor plak. Kemudian langsung dilakukan pengaplikasian three-tone plaque disclosing gel sebagai kontrol positif kemudian dilakukan penilaian terhadap skor plak. Penilaian skor plak dengan menggunakan metode O'Leary yang melihat area terwarnai pada bagian labial, lingual, mesial dan distal. Adapun perhitungan dengan metode O'Leary sebagai berikut =

$$
\frac{\text { Jumlah permukaan area terwarnai }}{\text { Total permukaan gigi yang diperiksa }} \times 100 \%
$$

\section{Analisis Data}

Data yang diperoleh berupa data rasio yang akan dianalisis menggunakan uji t-test. Pada awalnya dilakukan uji normalitas, Formula 1 (10\%) tidak terdistribusi normal sehingga diperlukan uji non parametrik dan Formula 2 (15\%) terdistribusi normal sehingga diperlukan uji parametrik. Perbandingan mean antara gel mukoadhesif kulit buah naga merah dengan three-tone plaque disclosing gel digunakan untuk melihat tingkat keefektifan gel mukoadhesif kulit buah naga merah dalam mewarnai plak gigi.

\section{HASIL PENELITIAN}

\section{Ekstrak Kulit Buah Naga Merah}

Tabel 3. Hasil Ekstraksi Kulit Buah Naga Merah

\begin{tabular}{lll}
\hline No. & Keterangan & Berat \\
\hline 1. & Kulit Buah Naga & $8 \mathrm{~kg}$ \\
\hline 2. & Ekstrak & $12,23 \mathrm{~g}$ \\
\hline
\end{tabular}

\section{Kandungan Betasianin}

Penentuan kadar betasianin dengan alat Spektrofotometer UV-Vis dengan pembacaan pada panjang gelombang $537 \mathrm{~nm}$

Dari pembacaan tersebut, kadar betasianin dihitung dengan rumus :

$$
\begin{aligned}
& \text { Kadar Betasianin }\left(\frac{\mathrm{mg}}{\mathrm{l}}\right)=\frac{A \times F P \times B M \times 1000}{\Sigma \times L} \\
& =\frac{0.564 \times 1 \times 550 \times 1000}{60000 \times 1} \\
& =5.17 \mathrm{mg} / \mathrm{l}
\end{aligned}
$$

\section{Formulasi Gel Mukoadhesif}

Pembuatan gel mukoadhesif kulit buah naga merah terdiri dari dua konsentrasi yaitu $10 \%$ dan

\begin{tabular}{|c|c|c|c|}
\hline \multicolumn{4}{|c|}{ Uji Organoleptis } \\
\hline & Karakteristik & $\begin{array}{l}\text { Formula } 1 \\
(10 \%)\end{array}$ & $\begin{array}{l}\text { Formula } 2 \\
(15 \%)\end{array}$ \\
\hline 1. & Wujud & $\begin{array}{l}\text { Massa } \\
\text { gel kental }\end{array}$ & $\begin{array}{l}\text { Massa gel } \\
\text { kental }\end{array}$ \\
\hline 2. & Warna & Merah & Merah tua \\
\hline 3. & Bau & $\begin{array}{l}\text { Berbau } \\
\text { khas } \\
\text { ekstrak }\end{array}$ & $\begin{array}{l}\text { Berbau } \\
\text { khas } \\
\text { ekstrak }\end{array}$ \\
\hline \multicolumn{4}{|c|}{ Uji Daya Lekat } \\
\hline 4. & Daya Lekat (detik) & 0,45 detik & 1,10 detik \\
\hline \multicolumn{4}{|c|}{ Uji Daya Sebar } \\
\hline 5. & Daya Sebar (cm) & $4,56 \mathrm{~cm}$ & $4,75 \mathrm{~cm}$ \\
\hline
\end{tabular}
$15 \%$. Adapun hasil uji kontrol kualitas sebagai berikut:

Tabel 4. Hasil Uji Kontrol Kualitas Gel Mukoadhesif 


\section{Uji Klinis}

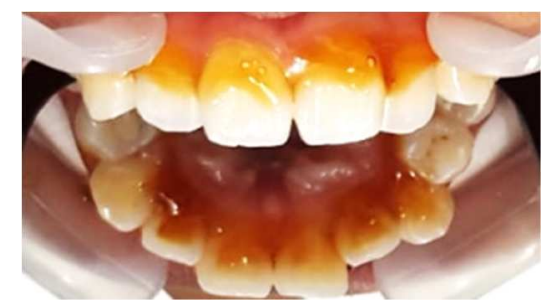

(A)

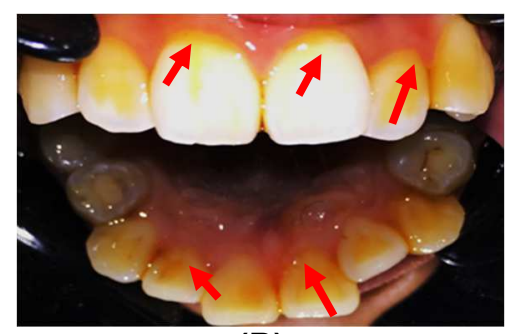

(B)

Gambar 1. Gambaran uji klinis pengaplikasian Gel Mukoadhesif Ekstrak Kulit Buah Naga Merah Kondentrasi 10\%. (A) Sebelum berkumur, (B) Setelah Berkumur

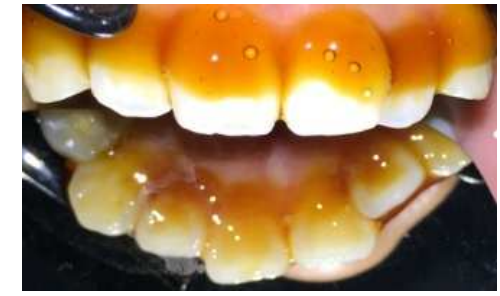

(A)

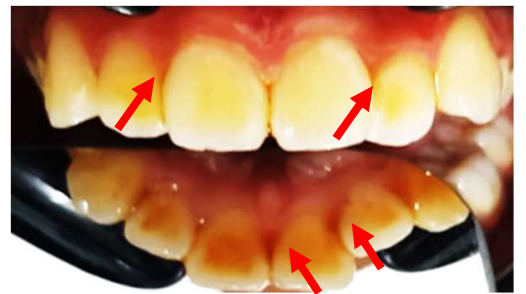

(B)

Gambar 2. Gambaran uji klinis pengaplikasian Gel Mukoadhesif Ekstrak Kulit Buah Naga Merah Kondentrasi 15\%. (A) Sebelum berkumur, (B) Setelah Berkumur

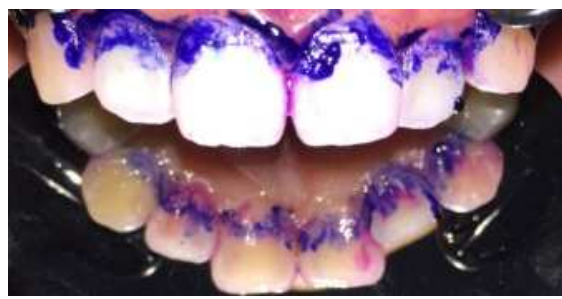

(A)

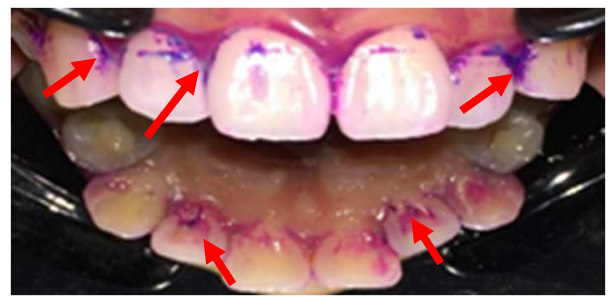

(B)

Gambar 3. Gambaran uji klinis pengaplikasian three-tone plaque disclosing gel. (A) Sebelum berkumur, (B) Setelah Berkumur

Tabel 5. Distribusi frekuensi kritera Plak Indeks sesudah pengolesan Gel Mukoadhesif Ekstrak Kulit Buah Naga Merah Konsentrasi 10\% dan Threetone plaque disclosing gel

\begin{tabular}{|c|c|c|c|c|}
\hline \multirow{2}{*}{$\begin{array}{l}\text { Kriteria indeks } \\
\text { plak }\end{array}$} & \multicolumn{2}{|c|}{$\begin{array}{c}\text { Formula } 1 \\
(10 \%)\end{array}$} & \multicolumn{2}{|c|}{$\begin{array}{c}\text { Three-Tone Plaque } \\
\text { Disclosing Gel }\end{array}$} \\
\hline & $\mathrm{N}$ & $\%$ & $\mathrm{~N}$ & $\%$ \\
\hline $\begin{array}{l}\text { Baik } \\
(0-20 \%)\end{array}$ & 5 & 62,5 & 0 & 0 \\
\hline Sedang (21-40\%) & 2 & 25 & 1 & 12,5 \\
\hline $\begin{array}{l}\text { Buruk } \\
\text { (41-60\%) }\end{array}$ & 0 & 0 & 2 & 25 \\
\hline $\begin{array}{l}\text { Buruk Sekali } \\
(61-100 \%)\end{array}$ & 1 & 12,5 & 5 & 62,5 \\
\hline Jumlah & 8 & 100 & 8 & 100 \\
\hline Rata-rata & \multicolumn{2}{|c|}{22,08} & \multicolumn{2}{|c|}{66,21} \\
\hline
\end{tabular}

Tabel 6. Distribusi frekuensi kritera Plak Indeks sesudah pengolesan Gel Mukoadhesif Ekstrak Kulit Buah Naga Merah Konsentrasi 15\% dan Threetone plaque disclosing gel

\begin{tabular}{|c|c|c|c|c|}
\hline \multirow{2}{*}{$\begin{array}{l}\text { Kriteria indeks } \\
\text { plak }\end{array}$} & \multicolumn{2}{|c|}{$\begin{array}{c}\text { Formula } 2 \\
(15 \%)\end{array}$} & \multicolumn{2}{|c|}{$\begin{array}{c}\text { Three-Tone Plaque } \\
\text { Disclosing Gel }\end{array}$} \\
\hline & $\mathrm{N}$ & $\%$ & $\mathrm{~N}$ & $\%$ \\
\hline $\begin{array}{l}\text { Baik } \\
(0-20 \%)\end{array}$ & 4 & 50 & 0 & 0 \\
\hline $\begin{array}{l}\text { Sedang }(21- \\
40 \%)\end{array}$ & 1 & 12,5 & 1 & 12,5 \\
\hline $\begin{array}{l}\text { Buruk } \\
(41-60 \%)\end{array}$ & 3 & 37,5 & 2 & 25 \\
\hline $\begin{array}{l}\text { Buruk Sekali } \\
(61-100 \%)\end{array}$ & 0 & 0 & 5 & 62,5 \\
\hline Jumlah & 8 & 100 & 8 & 100 \\
\hline Rata-rata & & & & \\
\hline
\end{tabular}


Perbandingan Plak Indeks Antara Gel Mukoadhesif Ekstrak Kulit Buah Naga Merah dan Three-tone Plaque Disclosing Gel

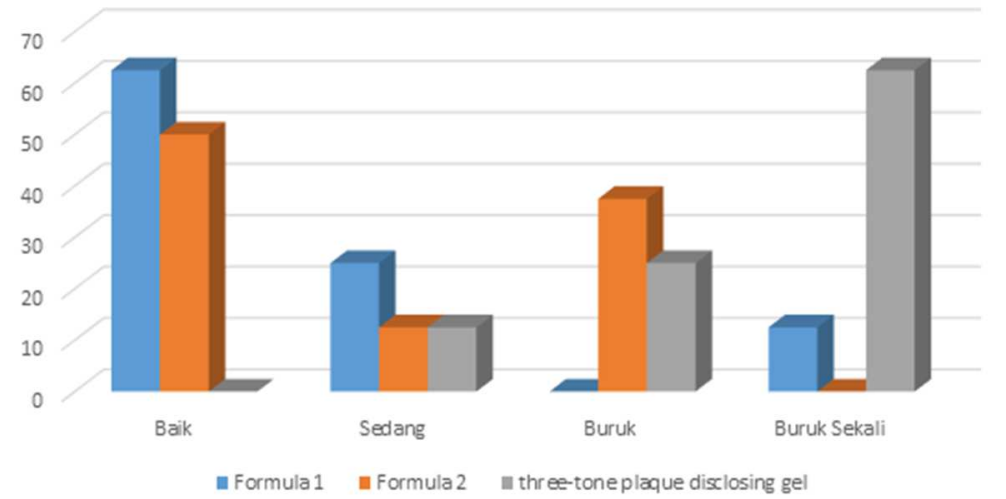

Gambar 6. Perbandingan plak indeks antara gel mukoadhesif ekstrak kulit buah naga merah dan three-tone plaque disclosing gel

Tabel 5 menunjukkan bahwa indeks plak paling tinggi pada aplikasi Formula 1 (10\%) yaitu $62,5 \%$ kategori baik dan aplikasi three-tone plaque disclosing gel yaitu $62,5 \%$ kategori buruk sekali. Sedangkan tabel 6 menunjukkan bahwa indeks plak paling tinggi pada aplikasi Formula 2 (15\%) yaitu $50 \%$ kategori baik dan aplikasi three-tone plaque disclosing gel yaitu $62,5 \%$ kategori buruk sekali.

Tabel 7. Nilai rata-rata Hasil Hitung Plak dengan metode O'Leary

\begin{tabular}{cccc}
\hline & Formula 1 (10\%) & \multicolumn{2}{c}{$\begin{array}{c}\text { Three-Tone Plaque } \\
\text { Disclosing Gel }\end{array}$} \\
\hline $\mathrm{n}$ & Mean & $\mathrm{n}$ & Mean \\
\hline 8 & 22,08 & 8 & 66,21 \\
\hline & Formula 2 (15\%) & \multicolumn{2}{c}{$\begin{array}{c}\text { Three-Tone Plaque } \\
\text { Disclosing Gel }\end{array}$} \\
\hline $\mathrm{n}$ & Mean & $\mathrm{n}$ & Mean \\
\hline 8 & 26,29 & 8 & 64,20 \\
\hline
\end{tabular}

Dari data yang didapatkan menunjukkan bahwa nilai kemaknaan (Sig.) Shapiro-wilk dari formula 1 (10\%) kurang dari 0,05 sehingga data tersebut tidak terdistribusi normal. Selanjutnya dapat dilakukan uji non parametrik dengan MannWhitney Test menunjukkan bahwa terdapat perbedaan rata-rata antara Formula 1 (10\%) dengan three-tone plaque disclosing gel. Hal ini dilihat bahwa Exact Sig. kurang dari 0,05 yang menunjukan adanya perbedaan yang signifikan antara hasil pewarnaan disclosing agent gel mukoadesif kulit buah naga merah (10\%) dan threetone plaque disclosing gel.

Sedangkan nilai kemaknaan (Sig.) Shapirowilk dari formula $2(15 \%)$ kurang dari 0,05 sehingga data tersebut tidak terdistribusi normal. Selanjutnya dapat dilakukan uji parametric dengan independent t-test menunjukkan bahwa ada perbedaan rata-rata antara Formula 2 (15\%) dan three-tone plaque disclosing gel. Hal ini terlihat dari nilai kemaknaan kurang dari 0,05 yang menunjukan adanya perbedaan yang signifikan antara hasil pewarnaan disclosing agent gel mukoadesif kulit buah naga merah (15\%) dan three-tone plaque disclosing gel. Untuk melihat tingkat efektivitas dari formula gel mukoadhesif maka dilakukan perbandingan antara rata-rata dari indeks plak formula dengan indeks plak three-tone plaque. Sehingga didapatkan hasil bahwa Formula $1(10 \%)$ memiliki tingkat keefektifan $33,87 \%$ sedangkan formula 2 (15\%) memiliki tingkat keefektifan sebesar $40,32 \%$.

$$
\begin{aligned}
& \text { Formula } 1=\frac{22.08}{65.21} \times 100 \%=33.87 \% \\
& \text { Formula } 2=\frac{26.29}{65.21} \times 100 \%=40.32 \%
\end{aligned}
$$




\section{DISKUSI}

Penelitian ini dilakukan untuk mengetahui kandungan serta potensi betasianin kulit buah naga merah (Hylocereus polyrhizus) dalam formula gel mukoadhesif sebagai alternatif disclosing agent. Pada penelitian ini terdapat dua sediaan gel mukoadhesif dengan kandungan ekstrak kulit buah naga merah sebanyak $10 \%$ dan $15 \%$ serta kontrol positif dengan Three-Tone Plaque Disclosing Gel.

Hasil penelitian menunjukkan bahwa plak gigi yang mulanya berwarna transparan menjadi berwarna kemerahan dengan pengaplikasian gel mukoadhesif ekstrak kulit buah naga merah dan tampak warna ungu-biru dengan pengaplikasian Three-Tone Plaque Disclosing Gel. Plak gigi tampak berwarna merah akibat kandungan betasianin yang terdapat dalam kulit buah naga merah $^{9}$. Pewarnaan plak gigi dengan disclosing agent terjadi karena adanya perbedaan polaritas antara komponen plak dan sediaan disclosing agent. Komponen plak berupa glikoprotein yang merupakan protein dengan rantai oligosakarida ${ }^{11}$.

Hasil uji kandungan betasianin kadar betasianin dalam ekstrak kulit buah naga merah yaitu $5,17 \mathrm{mg} / \mathrm{L}$. Pada penelitian sebelumnya, telah dievaluasi bahwa kandungan betasianin pada ekstrak kulit buah naga merah sebesar $13,8 \mathrm{mg} / \mathrm{I}^{13}$. Hasil tersebut lebih besar daripada kadar pigmen betasianin yang dihasilkan pada penelitian ini. Perbedaan kadar pigmen ini dipengaruhi oleh jenis dan karakter buah naga, kondisi serta tingkat kematangan saat pemanenan ${ }^{14}$.

Uji organolesptis dilakukan untuk mengetahui tampilan gel mukoadhesif yang berupa wujud, warna, dan bau. Hasil uji organoleptis menunjukkan bahwa semakin besar kadar ekstrak kulit buah naga merah dalam formula akan memberikan intensitas warna yang lebih pekat. Setiap formula berbau khas ekstrak kulit buah naga merah dan memiliki penampilan massa gel yang kental. Maka diketahui peningkatan kadar ekstrak kulit buah naga merah dalam formulasi gel akan berpengaruh pada organoleptis sediaan tersebut terutama pada intensitas warna.

Uji daya lekat untuk mengetahui kemampuan gel melekat pada gigi dalam waktu tertentu sehingga dapat berfungsi secara maksimal pada pewarnaan plak gigi. Hasil uji daya lekat diketahui waktu paling cepat daya lekat gel dengan kadar ekstrak terendah (10\%) selama 0,45 detik. Sedangkan, waktu daya lekat gel paling lama adalah gel dengan kadar ekstrak tertinggi (15\%) dengan waktu 1,10 detik. Kandungan air yang lebih banyak dan viskositas lebih rendah menjadikan waktu daya lekat gel dengan kadar terendah (10\%) lebih cepat bila dibandingkan dengan gel yang mengandung kadar ekstrak lebih tinggi. Sehingga formula dengan konsentrasi $15 \%$ memiliki kemampuan melekat pada gigi lebih baik bila dibandingkan formula konsentrasi $10 \%$.

Uji daya sebar untuk mengetahui kemampuan penyebaran gel pada gigi. Semakin besar daya sebarnya, zat aktif yang terkandung akan tersebar lebih merata dan lebih efektif dalam menghasilkan efek terapi. Daya sebar sediaan semipadat yang baik berkisar pada diameter 3-5 $\mathrm{cm}(14)$. Hasil uji daya sebar gel mukoadhesif menunjukkan daya sebar paling luas yaitu gel dengan kadar ekstrak tertinggi (15\%) dengan diameter penyebaran $4,75 \mathrm{~cm}$. Kadar ekstrak buah naga yang lebih besar, maka daya sebar akan semakin tinggi.

Gel mukoadhesif ekstrak kulit buah naga merah yang telah dilakukan berbagai uji diaplikasikan pada subjek penelitian yang telah dibagi menjadi 2 kelompok yaitu kelompok dengan formulasi $10 \%$ dan kelompok formuasi $15 \%$. Pengukuran indeks plak dilakukan dengan metode O'Leary hingga didapatkan rata-rata indeks plak dengan pengaplikasian gel konsentrasi 10\% 
sebesar 22,08\% dengan kontrol positif Three-Tone Plaque Disclosing $\mathrm{Gel} 66,21 \%$ dan dengan formulasi $15 \%$ sebesar $26,29 \%$ dengan kontrol positif Three-Tone Plaque Disclosing Gel 64,20\%.

Gel mukoadhesif ekstrak kulit buah naga merah konsentrasi $15 \%$ dapat mewarnai plak gigi sebanyak 40,32\% sedangkan konsentrasi 10\% mewarnai plak gigi sebanyak $33,87 \%$. Pewarnaan plak dengan gel mukoadhesif ekstrak kulit buah naga merah konsentrasi $15 \%$ lebih efektif dibandingkan konsentrasi $10 \%$.

Hal ini terjadi karena adanya perbedaan daya lekat produk dalam memberikan warna pada plak. Apabila sediaan disclosing agents memiliki perlekatan yang baik maka akan semakin baik pula dalam mewarnai plak gigi. Selain itu, kandungan betasianin pada kulit buah naga merah memiliki sifat hidrofilik ${ }^{16}$. Pada lingkungan gigi terdapat cairan rongga mulut sehingga betasianin akan berikatan dengan cairan dan berakibat pada tidak kuatnya ikatan betasianin dengan glikoprotein pada plak $^{17}$.

Pembersihan plak gigi sangat penting untuk tindakan pencegahan. Pewarnaan plak dengan disclosing agent yang adekuat akan memudahkan dalam pembersihan plak gigi. Apabila terdapat plak yang tidak terwarnai maka pembersihan plak menjadi tidak adekuat. Akumulasi plak yang tidak dibersihkan akan mengakibatkan adanya peradangan akibat perlawanan imun fisiologis terhadap produk bakteri dari dental plak. Peradangan inilah yang sering dikenal sebagai gingivitis 6,18 .

\section{KESIMPULAN}

Gel mukoadhesif kulit buah naga merah memiliki potensi untuk mewarnai plak gigi. Pada formula konsentrasi $15 \%$ yang lebih efektif dalam mewarnai plak gigi yaitu sebesar 40,32\% dari keseluruhan plak di permukaan gigi.

\section{UCAPAN TERIMAKASIH}

Penulis mengucapkan terima kasih kepada Kementrian Ristekdikti yang telah memberikan bantuan finansial dan Fakultas Kedokteran Gigi serta Fakultas Farmasi Universitas Gadjah Mada yang telah memberikan sarana untuk penelitian ini.

\section{DAFTAR PUSTAKA}

1. Newman MG, Takei HH, Klokkevold PR. Carranza's Clinical periodontology. 12th ed. Missouri: Elsevier Saunders; 2015. 163, hal.

2. Notohartojo IT, Sihombing M. Faktor Risiko Pada Penyakit Jaringan Periodontal Gigi di Indonesia (RISKESDAS 2013). Bul Penelit Sist Kesehat. 2015;18(1):87-94.

3. Kemenkes RI. Laporan Nasional Riset Kesehatan Dasar. Kementerian Kesehatan RI, 2018;203.

4. Chapple ILC, Van Der Weijden F, Doerfer C, Herrera D, Shapira L, Polak D, et al. Primary prevention of periodontitis: Managing gingivitis. J Clin Periodontol. 2015;42(S16):S71-6.

5. Datta D, Kumar SGR, Mb AN, Selvamary L, Sujatha A. Disclosing Solutions Used in Dentistry. World J Pharm Res. 2017;6(6):164856.

6. Fasoulas A, Pavlidou E, Petridis D, Mantzorou M, Seroglou K, Giaginis C. Detection of dental plaque with disclosing agents in the context of preventive oral hygiene training programs. Heliyon [Internet]. 2019;5(7):e02064. Tersedia pada:

https://doi.org/10.1016/j.heliyon.2019.e02064

7. Darby ML, Walsh MM. Dental Hygiene Theory and Practice. 4th Editio. Missouri: Elsevier; 2015. hal. 283

8. Dixit UB, Joshi A V. Effectiveness of plaque removal with an experimental chewable brush in children between age 9 and 13 years. Eur Arch Paediatr Dent [Internet]. 2018;19(6):417$21 . \quad$ Tersedia pada: http://dx.doi.org/10.1007/s40368-018-0376-2

9. Purnomo B, Hamzah F, Johan V. Pemanfaatan Kulit Buah Naga Merah (Hylocereus polyrhizus) Sebagai Teh Herbal. Jom Faperta [Internet]. 2016;3(2):1-10. Tersedia pada: https://media.neliti.com/media/publications/200 208-none.pdf

10. Mangiri BS, Yani S, Anitasari S. Sari buah naga super merah (Hylocereus costaricensis) Sebagai Pewarna Alami Plak Gigi. J Mater Kedokt Gigi. 2018;7(1):28-34.

11. Handayani PA, Rahmawati A. Pemanfaatan Kulit Buah Naga (Dragon Fruit) Sebagai Pewarna Alami Makanan Pengganti Pewarna Sintesis. J Bahan Alam Terbarukan. 
2013;1(2):19-24.

12. Langley C, Belcher D. Pharmaceutical Compounding and Dispensing. J Am Med Assoc. 2008;143(9).

13. Wu LC, Hsu HW, Chen YC, Chiu CC, Lin YI, Ho JAA. Antioxidant and Antiproliferative Activities of Red Pitaya. Food Chem. 2006;95(2):319-27.

14. Sumaya-Martínez MT, Cruz-Jaime S, MadrigalSantillán E, García-Paredes JD, Cariño-Cortés $\mathrm{R}$, Cruz-Cansino $\mathrm{N}$, et al. Betalain, Acid Ascorbic, Phenolic Contents and Antioxidant Properties of Purple, Red, Yellow and White Cactus Pears. Int J Mol Sci. 2011;12(10):645268.

15. Garg A, Aggarwal D, Garg S, Singla AK. Spreading of Semisolid Formulations: An update. Pharm Technol North Am.
2002;26(9):84-105.

16. Syarifa Ramadhani Nurbaya, Putri WDR, Murtini ES. Pengaruh Campuran Pelarut Aquades-Etanol Terhadap Karakteristik Ekstrak Betasianin dari Kulit Buah Naga Merah (Hylocereus polyrhizus). J Teknol Pertan. 2018;19(3):153-60.

17. Ekoningtyas EA, Triwiyatini, Nisa F. Potensi Kandungan Kimiawi Dari Ubi Jalar Ungu (Ipomoea Batatas L) Sebagai Bahan Identifikasi Keberadaan Plak Pada Permukaan Gigi. J Kesehat Gigi. 2016;03(1):1-6.

18. Murakami S, Mealey BL, Mariotti A, Chapple ILC. Dental Plaque-induced Gingival Conditions. J Clin Periodontol. 2018;45(August 2017):S17-27. 